\title{
The Influence of Using Chain Story Activity on Procedural Text towards Students' Speaking Skill
}

\author{
Iponiasih $^{1}$ \\ ${ }^{1}$ Madrasah Ibtidaiyah Mathla'ul Anwar Pusat Menes
}

\begin{abstract}
This research aims to find out the influence of using chain story activity on procedural text towards students' speaking skill. The researcher employs quantitative research with the method of experiment. She uses quasi experimental design in the type of nonequivalent control group to get the sample. The population are 157 students of the second grade students of Madrasah Aliyah Mathla'ul Anwar Pusat Menes. The samples are 26 students of the XI IPA 2 as the experimental class which is treated by using chain story activity and 24 students of XI IPA Tahfidz as the control class which is treated without using chain story activity. The data is collected by using oral test. The test are divided into two, pre-test and post-test. After the process of collecting the data finished, the researcher analizes them by using statistical computation. Based on the research findings after calculating the data, the result shows that there is significant influence of using chain story activity on procedural text towards students' speaking skill.
\end{abstract}

\section{INTRODUCTION}

English is the first foreign language to be taught in schools and becomes one of the subjects that arise in National Examination. It makes English as the important subject that should be mastered by the students. There are four basic skills in English that should be learnt by them who want to master English. They are listening, reading, writing, and speaking. Ur (2009:120) states that of all the four skills (listening, speaking, reading and writing), speaking seems intuitively the most important skill. Luoma (2004:1) adds that speaking skills are an important part of the curriculum in language teaching. It is due to the purposes of learning English itself. That is to assist students to be able to communicate in the real context. By having good ability in speaking, the students will have a good chance to communicate and interact better. Besides, nowadays many job vacancies which need people who can speak English fluency. So, speaking is considerd as the most important skill that should be mastered by the students.

\footnotetext{
${ }^{1}$ Corresponding author's address: Madrasah Ibtidaiyah Mathla'ul Anwar Pusat Menes, Banten, Indonesia

e-mail: iponiasihputri5895@gmail.com
} 
Ideally, the second grade students of Senior High School are able to arrange the text in the spoken or written form, at least in form of a simple text. It has been stated on the Standard Competencies and Basic Competencies (SK, KD) in the curriculum 2013. Besides, the policy of the school also determines the minimum passing grade score that should be attained by the students; at least the Minimal Criteria of Achievement (KKM) considering English subject to gain score 70 (seventy). However, to help all of the students in gaining that score is not simple for most students who are non-native speakers.

The obstructions that are commonly confronted by the students in speaking are varies. Ur (2009:121) says that there are four problems which are mostly experienced by students in the speaking activities. Those are inhibition, nothing to say, low or uneven participation, and mother-tongue use.

In addition, based on the result of the preliminary observation at Madrasah Aliyah Mathla'ul Anwar Pusat Menes on March 16 ${ }^{\text {th }}$ 2016, the researcher found that speaking represents a real challenge to the most students because unfortunately most of them were lack of vocabulary and the mastery of grammar pattern therefore they are afraid that their friends would laugh at them if they made mistakes. The other problems were the confusion about what topic they had to talk, when and where they had to start to speak English because they thought that they did not have partner and stage. The students also admit that they had nothing to say because there were no other students who speak with them to become their partner.

This phenomenon might be the cause of the lack confidence to speak English. Besides, that was also made the low achievement in understanding the English material comprehensively.

To solve the students' problem in speaking, there must be suitable and relevance activities. Ur (2009:121) explains five things about what the teacher can do to help and to solve some of the students' problems in speaking. The first is use group work. This activity will help the students try to talk and also lowers the inhibitions of them who are unwillingly to speak in English. Although, not all utterance will be correct but at least they practice to speak. The second is base the activity on easy language. This point tells us about the vocabulary that is used in the classroom activity should be easily recalled and produced by the students, so that they can speak with the minimum of hesitation. It will be better if the teacher reviews essential vocabulary before the activity starts. The third is making a careful choice of topic and task to stimulate interest. Try to choose a good topic to attract the students' interest to speak. The fourth is giving some instruction or training in discussion skills. It means make sure that everyone in the group contributes to the discussion. The last is keep students speaking the target language. Furthermore, considering what was stated by Harmer (2007:94) that some teachers can get very involved during a speaking activity, there is nothing wrong the teachers getting involved but don't start to dominate. Hence, the students will have time to explore their opinion and speak comfortably.

There are various activities that have been developed by the experts to help the students in increasing their abilities, interests, and motivations in speaking. Of all the activities, of course, is to attain the successful speaking class. Ur (2009:120) states about the characteristic of a successful speaking activity, such as; learners talk a lot, participation is even, motivation to speak up is high, and language that used is in an acceptable level.

In this case, the researcher interested to solve students' problem concerning the students' speaking skill at this school by proposing one of chain activities. There are three kinds of chain activities. They are chain game, chain drills, and chain story. In this research, chain story activity is the activity that is used by the researcher.

According to Erben cited in Gamal, et al (2017:3) says that chain story is an activity in which stories are written or made by multiple author; each author contributes a sentence to the story then forwards the entire text to a partner. In addition, Narendra (2016:4) says that chain story activity is 
kind of game which can be applied in language teaching and learning activity. In English teaching and learning activity, this activity can be applied in helping students to master speaking skill.

Considering that chain story is an activity that constructs text by continuing the previous given sentences with the peers in order to make a complete passage so that conducting chain story activity in class can help the students contribute equally in producing the story, even for them who are often unwilling to speak in English. Furthermore, Putra (2013:2) adds that the greatest advantage in chain story is that it is interesting and makes the activity of the learning process enjoyable for the students.

In the extent of time, chain story is activity which is well-known not only these days but also in the very long time ago. It is proved by some experts who write about this activity in their book, like Klippel (1984) and Molinsky (1994). They write the steps of how to use chain story activity for speaking class.

Based on the analyzed problems and some theories above, the researcher decided to conduct the research to investigate the influence of using chain story activity on procedural text towards students' speaking skill at the second grade students of Madrasah Aliyah Mathla'ul Anwar Pusat Menes.

\section{METHOD}

In line with the purpose, the goal of this research was to know whether there is an influence of chain story activity towards students' speaking skill or not. It was suitable with one of the characteristic of quantitative research method. Fraenkle, et al (2011:265) states that experimental research is one of the most powerful research methodologies that the researcher can use. From many types of research that might be used, the experiment is the best way to establish cause-and-effect relationships among variables. By using this method, the researcher implemented treatments to the sample and then studied their effect. Results from the treatment of the research were likely to lead to the clear interpretation. It means the researcher knew the effect by seeing directly the evidence in the result of the research, whether there was the effect of using chain story activity in improving the students' speaking skill or not.

There are four designs in experimental method. One of them is quasi experimental design. In this research, the researcher used the non-equivalent control group design because this design was suitable with the process of the research. According to Sugiyono (2011:79) the non-equivalent control group design can be drawn as follows:

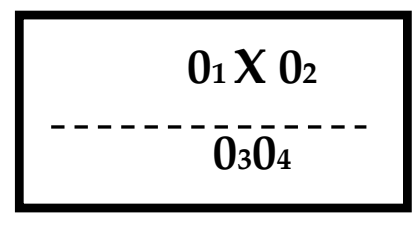

Where:

$0_{1}$ : The pre-test result of the experimental class

$0_{3}$ : The pre-test result of the control class

$X$ : The treatments

$\mathbf{0}_{2}$ : The post-test result of the experimental class

$\mathbf{0}_{4}$ : The post-test result of the control class 
In taking the sample from the whole population of the second grade students of Madrasah Aliyah Mathla'ul Anwar Pusat Menes in 2016/2017 academic year which consists of six classes, the researcher used the purposive sampling technique. The samples of this research were the XI IPA 2 which consists of 26 students treated as the experimental class and taught by using chain story activity and the XI Tahfidz which consists of 24 students as the control class taught by using conventional activities.

Considering that this research was aimed to investigate the difference influence between two different activities, which is better, so that testing of hypothesis needed to use tails hypothesis. The hypotheses of this research are:

$\mathrm{H}_{0}$ : There is no significant influence of using chain story activity on procedural text towards students' speaking skill.

$\mathrm{H}_{a}$ : There is significant influence of using chain story activity on procedural text towards students speaking skill.

In this case, if the result of $t_{\text {.count }}>t$ table or null hypothesis $\left(\mathrm{H}_{0}\right)$ was rejected and then alternative hypothesis $\left(\mathrm{H}_{\mathrm{a}}\right)$ was accepted it means that there is significant influence of using chain story activity on procedural text towards students' speaking skill. On the other hand, if the result of t.count $<$ t.table or null hypothesis $\left(\mathrm{H}_{0}\right)$ was accepted and alternative hypothesis $\left(\mathrm{H}_{\mathrm{a}}\right)$ was rejected, it means that there is no significant influence of using chain story activity on procedural text towards students' speaking skill.

\section{RESULT AND DISCUSSION}

The objective of this research was to find out whether there is or there is no significant influence of using chain story activity on procedural text towards students' speaking skill. However, in the extent of the teaching material, the researcher also has to be well prepared in assisting the students to understand about procedural text. Due to the syllabus of English subject that procedural text is one of the text genres that should be taught to the students at the second grade of Senior High School.

The following are the steps in implementing chain story activity that were taken based on the journal of Putra (2013:4), entitled Using Chain Stories to Improve the Ability of the First Year Students of MA Dar-El Hikmah Pekanbaru in Writing Recount Texts. The writer changed several points of Putra's journal in order to make the learning process are enjoyable, fun, suitable with the students' ability in the place of this research held, and still in the line with the syllabus and the lesson plan. The steps provided as follows:

\section{Preparation}

1. The researcher constructed the students' mind and knowledge from the basic knowledge by asking the students' experience that related to procedural text.

2. The researcher gave some questions to encourage students' thinking ability about procedural text.

3. The researcher divided the students into groups of five.

4. The researcher gave a sample of a procedual text to each group and explains about it.

5. The researcher explained to the students the process of chain story activity.

6. The researcher gave the small slips of paper with one word on it as many as the students in the group.

7. The researcher gave the students 10 minutes to discuss and develop the story (the steps) with their friend in the group. 


\section{Action}

1. The researcher asked the first group of the students to come forward.

2. The researcher began the first sentence.

3. Students by the researcher of the first group continued the next sentence by contributing his/her steps. Each student is given time to give the contribution (more time needed as the steps grow longer and must include the word on his slip of paper.) It is better if each student could produce more than three sentences. The story had to be completed in each group.

4. The next group of the student goes on. (This pattern continuous until all of the students had contributed to the story).

5. After the group of the students performs and go back to their seat, they had to make their story neatly.

\section{Closing}

1. Students corrected the steps together led by the teacher in providing an edit checklist on the board to aid students in focusing on particular errors (vocabulary or grammatical structure).

2. The researcher terminated the class.

After several times treatment held in the experimental class, the researcher adds some variation in using chain story activity in the classroom. Like, each student was also given a number; the numbers determined the sequence in which the students had to contribute to the story and give the students a time to discuss the material lesser that 10 minutes.

In gaining the data needed for this research, the researcher gave the tests to the students. The test was divided into two phases, they were pre-test and post-test.

The pre-test was held before the researcher implements the treatment by using chain story activity in the experimental class while the post-test was held after doing treatments. So that the researcher can see and compare the differences in the data of the both test result. The same test also held in the control class but there was no treatment by using chain story activity in the process of teaching and learning.

In taking the data, the instrument that is used was oral achievement test. The following table is the scale of oral testing criteria in assessing the students' speaking skill that was applied in this research.

Table 1. The Scale of Oral Achievement Test

\begin{tabular}{|c|c|c|}
\hline No & Pronunciation & Score \\
\hline 1 & Errors in pronunciation are frequent & 1 \\
\hline 2 & $\begin{array}{l}\text { Makes obvious pronunciation mistakes butcan handle } \\
\text { elementary constructions control of the pronunciation }\end{array}$ & 2 \\
\hline 3 & $\begin{array}{l}\text { Mistakes in pronunciation are rare and can usually handle } \\
\text { elementary constructions control of the pronunciation }\end{array}$ & 3 \\
\hline 4 & Errors or mistakes in pronunciation are quite rare & 4 \\
\hline 5 & $\begin{array}{l}\text { No pronunciation errors or mistakes, fully accepted by } \\
\text { educated native speakers }\end{array}$ & 5 \\
\hline No & Pronunciation & Score \\
\hline 1 & Little or no communication & 1 \\
\hline 2 & $\begin{array}{l}\text { Very hesitant and brief utterances, sometimes difficult to } \\
\text { understand }\end{array}$ & 2 \\
\hline 3 & Gets idea across, but hesitantly and briefly & 3 \\
\hline 4 & Effective communication in short turns & 4 \\
\hline 5 & $\begin{array}{l}\text { Easy and effective communication uses long turns and the } \\
\text { speech is fully accepted by educated native speakers }\end{array}$ & 5 \\
\hline
\end{tabular}




\begin{tabular}{|c|c|c|}
\hline No & Vocabulary & Score \\
\hline 1 & Indequate vocabulary to express anything & 1 \\
\hline 2 & $\begin{array}{l}\text { Using vocabulary for most elementary needs and the } \\
\text { vocabulary is sufficient to express something }\end{array}$ & 2 \\
\hline 3 & $\begin{array}{l}\text { Adequate but not rich vocabulary and able to speak the } \\
\text { language sufficiently }\end{array}$ & 3 \\
\hline 4 & $\begin{array}{l}\text { Good range of vocabulary and able to speak the language } \\
\text { sufficiently }\end{array}$ & 4 \\
\hline 5 & $\begin{array}{l}\text { Wide vocabulary appropriately used and the speechfully } \\
\text { accepted by educated native speakers }\end{array}$ & 5 \\
\hline No & Grammar & Score \\
\hline 1 & Errors in grammars are frequent & 1 \\
\hline 2 & $\begin{array}{l}\text { Makes obvious grammar mistakes but can usually handle } \\
\text { elementry constructions control of the grammar }\end{array}$ & 2 \\
\hline 3 & $\begin{array}{l}\text { Occasional grammar mistakes and control of grammar is } \\
\text { good }\end{array}$ & 3 \\
\hline 4 & $\begin{array}{l}\text { Error or mistakes in grammar are quite rare and able to } \\
\text { use the grammar accurately }\end{array}$ & 4 \\
\hline 5 & $\begin{array}{l}\text { No grammar errors or mistakes and equivalent to that of } \\
\text { the educated native speakers }\end{array}$ & 5 \\
\hline No & Comprehension & Score \\
\hline 1 & to the tyne of sneer & 1 \\
\hline 2 & Little understands to the type of speech that they made & 2 \\
\hline 3 & Understands enough to the type of speech that they made & 3 \\
\hline 4 & $\begin{array}{l}\text { Undertsands quite well to the type of speech that they } \\
\text { made }\end{array}$ & 4 \\
\hline 5 & $\begin{array}{l}\text { Understands any kind of speech, equavalent to that of an } \\
\text { educated native speaker }\end{array}$ & 5 \\
\hline
\end{tabular}

Brown (2007:352)

The criteria of oral achievement test is divided into five elements as above. Then, the researcher objectively saw the caracteristics of each students' speech whetever they achieve 1,2,3,4, or 5 score on each of the elements. After that, the researcher calculated the score by using a simple equation as follows :

$$
\text { Score }=\frac{\text { Number of Correct Answer }}{\text { Total Number of Score (10) }} \times 100
$$

After getting the data, the researcher analized and calculated them by using statistical computation. The result can be seen in the following table.

Table 2. The Data Recapitulation of Experimental Class and Control Class

\begin{tabular}{llll}
\hline No & \multicolumn{1}{c}{ Description } & $\begin{array}{c}\text { Experimental } \\
\text { Class }\end{array}$ & $\begin{array}{c}\text { Control } \\
\text { Class }\end{array}$ \\
\hline 1 & Mean & 7.07 & 3.66 \\
\hline 2 & Standard Deviation & 3.21 & 2.74 \\
\hline 3 & Variance & 10.314 & 7.536 \\
\hline 4 & Samples & 26 & 24 \\
\hline & t-count & 24.357 & \\
\hline & t-table & 2.021 & \\
\hline
\end{tabular}

The table above shows that the mean of experimental class is 7.07 with 3.21 of standard deviation. Meanwhile the mean of control class is 3.66 with 2.74 of standard deviation. With 48 the score of the degree of freedom, the $t$-count is 24.357 and $t$-table is 2.021 . The $t$-table is found by using two tailed $t$-test 
formula in the 0.05 level of significant. It was clear that $t$-count is higher than $t$-table means null hypothesis $\left(\mathrm{H}_{0}\right)$ was rejected and the alternative hypothesis $\left(\mathrm{H}_{\mathrm{a}}\right)$ was accepted. It means that there was significant influence of using chain story activity on procedural text towards the students' speaking skill.

\section{CONCLUSIONS}

After conducting the research at the second grade students of Madrasah Aliah Mathla'ul Anwar Pusat Menes by giving them treatment used chain story activity in the experimental class and used conventional activities in the control class, the researcher knew that there was significant influence of using chain story activity on procedural text in improving the students' speaking skill. Based on the result of pre-test and post-test in both experimental and control class, the researcher found that the mean of experimental class was higher than the mean of control class. The result of post-test in experimental class has significantly improved that is $\mathrm{t}$-count $>\mathrm{t}$-table $=24.357>2.021$. It means that alternative hypothesis $\left(\mathrm{H}_{\mathrm{a}}\right)$ was accepted.

Based on the result of this research and conclusion above, the researcher proposes the following suggestions.

First, students are suggested to do this activity frequently not only inside but also outside the classroom with their friends and using other topic of their interest. It will help them better because they will find it more comfortable to speak if they do that with their friends and in the informal situation. Besides, chain story activity provides the steps which give all the students to have the same opportunity to speak English.

Second, if the teachers want to use this chain activity, they are not only should be well prepared with all of the possibility about the story will be formed but also have to prepare a good feedback from the story and the material towards the students.

Third, for the next researcher can investigate the influence of using chain story activity towards the other skill of English such as listening, and reading. Furthermore, they can use different kinds of text or material that should be learnt by the students in senior high school level and even in junior or elementary school level.

\section{REFERENCE}

Brown, H. D. (2007). Teaching by Principle, an Interactive Approach to Language Pedagogy Third Edition, New York: Pearson Longman.

Fraenkel, J.R. et al. (2011). How to Design and Evaluate Research in Education, New York: Mc Graw Hill.

Gamal, et al. (2017). The Effect of Chain Story in Writing Narrative Text on The Second Year Students of SMAN 5 Pekanbaru. Jurnal Online Mahasiswa Fakultas Keguruan dan Ilmu Pendidikan Universitas Riau. 05(01).

Harmer, J. (2007). How to Teach English, England: Pearson Education.

Luoma, S. (2004). Assessing speaking, United Kingdom: Cambridge University Press.

Narendra. (2016). The Implementation of Chain Story Game to Teach Speaking in Recount Text for Eighth Graders of SMPN 39 Surabaya. Jurnal Mahasiswa UNESA. 04(01).

Putra, A.P. (2013). Using Chain Stories to improve the Ability of the First year students of MA Dar-El Hikmah Pekanbaru in Writing Recount Texts. Riau: English Language Department, Faculty of Teachers' Training and Education, Riau University.

Sugiyono. (2011). Metode Penelitian Kuantitatif, Kualitatif dan RED. Bandung: Alfabeta.

Ur, P. (2009). A Course in Language Teaching. UK: Cambridge University Press. 